\title{
Ginkgo biloba and Helianthus annuus show different strategies to adjust photosynthesis, leaf water relations, and cell wall composition under water deficit stress
}

\author{
M. ROIG-OLIVER ${ }^{+, \dagger}$, M. NADAL ${ }^{\dagger}$ J. BOTA, and J. FLEXAS \\ Research Group on Plant Biology under Mediterranean Conditions, Department of Biology, Universitat de les Illes \\ Balears (UIB), INAGEA, Carretera de Valldemossa Km 7.5, 07122 Palma, Illes Balears, Spain
}

\begin{abstract}
Cell wall thickness $\left(\mathrm{T}_{\mathrm{cw}}\right)$ determines photosynthesis and leaf elasticity. However, only a few studies in angiosperms addressed cell wall composition implication in regulating photosynthesis and leaf water relations through mesophyll conductance $\left(g_{\mathrm{m}}\right)$ and bulk modulus of elasticity $(\varepsilon)$ adjustments, respectively. Thus, we compared the phylogenetically distant Ginkgo biloba L. and Helianthus annuus L. under control and water deprivation to study the relationship between changes in cell wall composition (cellulose, hemicelluloses, and pectins) with $g_{\mathrm{m}}$ and $\varepsilon$. Although no changes were found for $\mathrm{T}_{\mathrm{cw}}$, both species differently modified cell wall composition, resulting in different physiological consequences. $H$. annuus increased cellulose, hemicelluloses, and pectins in a similar proportion, maintaining $\varepsilon$. Additionally, it reduced photosynthesis due to stomatal closure. G. biloba did not decrease photosynthesis and largely increased hemicelluloses, leaf mass area, and leaf density, enhancing $\varepsilon$. Nonetheless, no association between cell wall composition and $g_{\mathrm{m}}$ was found in either of the two species.
\end{abstract}

Keywords: angiosperm; gymnosperm; leaf structure.

\section{Introduction}

Photosynthesis is a complex phenomenon that involves both diffusional and biochemical processes (Flexas et al. 2004, von Caemmerer et al. 2009). The diffusional process consists of the $\mathrm{CO}_{2}$ pathway from the atmosphere to the substomatal cavity (stomatal conductance, $g_{\mathrm{s}}$ ) across the mesophyll tissue (mesophyll conductance, $g_{\mathrm{m}}$ ) until reaching its carboxylation sites at chloroplasts stroma, where biochemical processes occur (Flexas et al. 2004, Evans et al. 2009, von Caemmerer et al. 2009). Even though the mechanistic nature of $g_{\mathrm{m}}$ is not yet fully understood (Evans et al. 2009, Flexas et al. 2012), some studies have evidenced that leaf anatomical traits, particularly cell wall thickness $\left(\mathrm{T}_{\mathrm{cw}}\right)$ and chloroplasts surface area exposed to intercellular air spaces per leaf area $\left(\mathrm{S}_{\mathrm{c}} / \mathrm{S}\right)$, are crucial to determine $g_{\mathrm{m}}$ across plants' phylogeny and in response to different environmental conditions (Terashima et al. 2001, Evans et al. 2009, Flexas et al. 2012, Tomás et al. 2013, Carriquí et al. 2015, 2019, 2020; Tosens et al. 2016, Onoda et al. 2017, Peguero-Pina et al. 2017, VeromannJürgenson et al. 2017). Hence, as thick cell walls limit $g_{\mathrm{m}}$ and, simultaneously, potentially increase cells rigidity (enhanced bulk modulus of elasticity, $\varepsilon$ ) (Tyree and Jarvis 1982, Peguero-Pina et al. 2017), a trade-off between $g_{\mathrm{m}}$ and net photosynthetic rate $\left(P_{\mathrm{N}}\right)$ with $\varepsilon$ was demonstrated in a wide range of species under nonstress conditions (Nadal et al. 2018). Nonetheless, the mechanistic basis of $\varepsilon$ and its intraspecific dynamics during plant's acclimation to changing environmental conditions are still poorly understood. Although Niinemets (2001) and Sack et al. (2003) proposed that leaf structure, particularly leaf mass

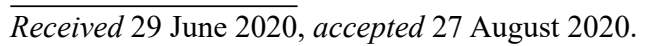

${ }^{+}$Corresponding author; e-mail: margaroig93@gmail.com

Abbreviations: $a_{\mathrm{f}}$ - apoplastic water fraction; AIR - alcohol insoluble residue; $C^{*}{ }_{\mathrm{ft}}-$ leaf area specific capacitance at full turgor; ETR - electron transport rate; $f_{\text {ias }}$ - fraction of mesophyll intercellular air spaces; $g_{\mathrm{m}}-$ mesophyll conductance; $g_{\mathrm{s}}-$ stomatal conductance; LA - leaf area; LD - leaf density; LMA - leaf mass area; $P_{\mathrm{N}}$ - net photosynthetic rate; $R_{\text {light }}$ - light respiration; $\mathrm{RWC}_{\mathrm{tp}}-$ relative water content at turgor loss point; $\mathrm{S}_{\mathrm{c}} / \mathrm{S}$ - chloroplasts surface area exposed to intercellular air spaces per leaf area; $\mathrm{T}_{\mathrm{cw}}-$ cell wall thickness; $\mathrm{WUE}_{\mathrm{i}}$ - intrinsic water-use efficiency; $\varepsilon$ - bulk modulus of elasticity; $\pi_{\mathrm{o}}$ - osmotic potential at full turgor; $\Psi_{\text {tlp }}-$ water potential at turgor loss point.

Acknowledgments: This work was supported by the project PGC2018-093824-B-C41 from the Ministerio de Ciencia, Innovación y Universidades (Spain), the ERDF, the UE and the AEI. M. Roig-Oliver and M. Nadal were supported by predoctoral fellowships FPU16/01544 and BES-2015-072578, respectively, from Ministerio de Economía y Competitividad (MINECO, Spain). Additionally, M. Nadal was co-supported by the European Social Fund. We thank Dr. María José Clemente-Moreno for her advice in results analyses and María Teresa Mínguez (Universitat de València, Secció de Microscòpia Electrònica - SCSIE) and Dr. Ferran Hierro (Universitat de les Illes Balears, Serveis Cientificotècnics) for technical support during microscopic analyses. We also thank Mr. Miquel Truyols and collaborators of the UIB Experimental Field and Glasshouses that are supported by the UIB Grant 15/2015.

Both authors contributed equally to this paper. 
area (LMA) and leaf density (LD), was the main driver of $\varepsilon$, more recent studies suggested that cell wall composition and properties could be also relevant for determining $\varepsilon$ (Moore et al. 2008, Solecka et al. 2008, Álvarez-Arenas et al. 2018, Roig-Oliver et al. 2020).

The plant cell wall, a complex structure considered as a protective barrier to face those biotic and abiotic stresses occurring during plants' life, is mainly compounded by cellulose microfibrils (Carpita and Gibeaut 1993, Cosgrove 1997, 2005; Somerville et al. 2004, Sarkar et al. 2009, Tenhaken 2015, Houston et al. 2016, Rui and Dinnery 2019). Between those closely packed microfibrils, noncellulosic neutral sugars (hereafter 'hemicelluloses') are placed, conferring stability to the wall (Carpita and Gibeaut 1993, Cosgrove 1997, 2005; Somerville et al. 2004, Sarkar et al. 2009, Tenhaken 2015, Rui and Dinnery 2019). This cellulose-hemicelluloses network is embedded in a pectin matrix which has been proposed as a crucial structure to maintain an appropriate cell wall hydric status, especially during water deficit stress (Vicré et al. 2004, Cosgrove 2005, Leucci et al. 2008, Moore et al. 2008, 2013; Schiraldi et al. 2012, Le Gall et al. 2015, Houston et al. 2016). Additionally, the pectin matrix seems to be a key structure determining wall porosity and thickness (Somerville et al. 2004, Cosgrove 2005, Tenhaken 2015, Houston et al. 2016, Rui and Dinnery 2019), leading to the suggestion that it could influence $\mathrm{CO}_{2}$ diffusion and, thus, photosynthesis. However, only a few studies directly focused on the relationship between modifications in cell wall components and $g_{\mathrm{m}}$ (Ellsworth et al. 2018, Clemente-Moreno et al. 2019, Carriquí et al. 2020, Roig-Oliver et al. 2020). Particularly, Ellsworth et al. (2018) provided first evidence on how $g_{\mathrm{m}}$ reductions could be attributed to anatomical alterations due to cell wall changes testing cslf6 rice mutants. Then, ClementeMoreno et al. (2019) specifically identified pectins and/ or the ratio of hemicelluloses to pectins as main drivers of $g_{\mathrm{m}}$ changes in Nicotiana sylvestris subjected to different environmental conditions. The relationship between modified cell wall composition and $g_{\mathrm{m}}$ changes could not be exclusively attributed to pectins as Roig-Oliver et al. (2020) showed that only cellulose correlated with $g_{\mathrm{m}}$ in Vitis vinifera cv. Grenache acclimated to contrasting conditions. Nonetheless, at an interspecific level and under nonstress conditions, the ratio of pectins to cellulose and hemicelluloses determined $g_{\mathrm{m}}$ in conifers (Carriquí et al. 2020). Thus, it appears that the relationship between cell wall main composition and $g_{\mathrm{m}}$ could be species-dependent (Roig-Oliver et al. 2020) and could be attributed to specific growing conditions.

Some studies have determined that cell wall composition differs among plants belonging to different phylogenetic groups (Popper and Fry 2004, Sørensen et al. 2010, Popper et al. 2011, Bartels and Classen 2017). Additionally, several studies have characterized cell wall composition changes in different monocot and dicot species under stressing conditions (see, for instance, Sweet et al. 1990, Vicré et al. 1999, 2004; Leucci et al. 2008, Moore et al. 2008, Solecka et al. 2008, Suwa et al. 2010, Carvalho et al. 2013, Baldwin et al. 2014, Zheng et al. 2014, Clemente-
Moreno et al. 2019, Roig-Oliver et al. 2020). However, to our knowledge, no information is known regarding stress-induced changes in cell wall properties in other plant groups. Moreover, how these differences in cell wall composition in response to stress could be linked to differed strategies to regulate photosynthesis, leaf water relations and anatomical adjustments remain to be elucidated. In the current study, we compared the gymnosperm living fossil Ginkgo biloba L. (Ginkgoaceae) and the herbaceous angiosperm Helianthus annuus L. (Asteraceae) acclimated to two different experimental conditions (well-watered, i.e., control, and water deficit stress) to induce changes in cell wall composition that could influence photosynthesis, anatomical and/or leaf water relations responses.

\section{Materials and methods}

Plant material and growth conditions: One-year-old G. biloba plants were acquired from a garden center in horticultural alveolus. $H$. annuus seeds were individually sewed in horticultural alveolus using a mixture of 3:1 substrate:perlite. All plants were placed in a growth chamber at $22^{\circ} \mathrm{C}$ with $12 / 12$-h light/darkness daily fluctuation receiving PPDF of $200-300 \mu \mathrm{mol} \mathrm{m}^{-2} \mathrm{~s}^{-1}$. Water irrigation was assessed every two days to ensure plant growth. Three weeks later, when all plants had fullydeveloped leaves, they were transplanted to $3-\mathrm{L}$ pots containing a mixture of 2:2 and 3:1 substrate:perlite for G. biloba and H. annuus, respectively. At this moment, six individual replicates per species were randomly subjected to two treatments: control (i.e., well-watered) and water deficit stress. Water-stressed plants were monitored every two days to maintain pots field capacity at $50 \%$ by replacing evapotranspired water and control plants were daily irrigated to keep field capacity at $100 \%$. To identify the onset of new leaves during plants' acclimation to experimental conditions, already emerged ones were labeled. In both cases, treatments lasted $40 \mathrm{~d}$. All measurements were performed in new fully developed leaves developed under control or water-stressed conditions.

Gas-exchange and fluorescence measurements: At the end of the treatments, simultaneous measurements of gas exchange and chlorophyll $a$ fluorescence with an open infrared gas-exchange system coupled with a $2-\mathrm{cm}^{2}$ fluorescence chamber (Li-6400-40XT, Li-Cor Inc., Lincoln, NE, USA) were performed in one leaf per plant in each species and treatment. Measurements were performed at saturating PPFD $\left(1,500 \mu \mathrm{mol} \mathrm{m}{ }^{-2} \mathrm{~s}^{-1}\right.$ for H. annuus; 1,250

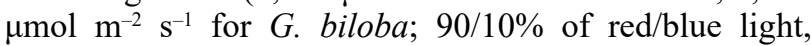
respectively, in both cases), $25^{\circ} \mathrm{C}$ block temperature, and $300 \mu \mathrm{mol} \mathrm{m^{-1 }}$ flow rate. All gas-exchange measurements were corrected for $\mathrm{CO}_{2}$ leakage in the leaf-gasket interface (Flexas et al. 2007). $P_{\mathrm{N}}, g_{\mathrm{s}}$, substomatal $\mathrm{CO}_{2}$ concentration $\left(C_{\mathrm{i}}\right)$, and photochemical yield of PSII $\left(\Phi_{\mathrm{PSII}}\right)$ were recorded after steady-state conditions were reached (15-30 min) at ambient $\mathrm{CO}_{2}$ concentration $\left(C_{\mathrm{a}}\right)$ of $400 \mu \mathrm{mol} \mathrm{mol}{ }^{-1} . P_{\mathrm{N}}-C_{\mathrm{i}}$ response curves were then performed by changing $C_{\mathrm{a}}$ in 14 steps (3-4 min), from 50 to $1,500 \mu \mathrm{mol}\left(\mathrm{CO}_{2}\right) \mathrm{mol}^{-1}$ (air). Light curves under nonphotorespiratory conditions $(1 \%$ 
$\mathrm{O}_{2}$ ) were performed to determine light respiration $\left(R_{\text {light }}\right)$ and the PPFD fraction harvested by PSII ( $s$ ) (Yin et al. 2009, 2011; Bellasio et al. 2016). From previous parameters, the electron transport rate (ETR) was calculated as described in Bellasio et al. (2016). The $\mathrm{CO}_{2}$-compensation point in the absence of respiration $\left(\Gamma^{*}\right)$ for G. biloba and $H$. annuus were obtained from comparing $P_{\mathrm{N}}-C_{\mathrm{i}}$ curves under ambient $(21 \%)$ and low $\mathrm{O}_{2}(1 \%)$ conditions as described in Bellasio et al. (2016). Finally, mesophyll conductance $\left(g_{\mathrm{m}}\right)$ was determined by the curve-fitting method (Sharkey 2016) using $R_{\text {light }}$ as an input and the Rubisco kinetics $\left(K_{\mathrm{c}}, K_{\mathrm{o}}\right)$ from tobacco (Bernacchi et al. 2002). The mean $\Gamma^{*}$ value obtained for each species under well-watered conditions was used for water-stressed plants as in vivo methods are not reliable under stress (Galmés et al. 2006).

Anatomical measurements: A portion of the leaves used for gas-exchange measurements were cut in small pieces avoiding main foliar structures to be fixed under vacuum pressure using glutaraldehyde 4\% and paraformaldehyde $2 \%$ prepared in $0.01 \mathrm{M}$ phosphate buffer ( $\mathrm{pH} 7.4$ ). Samples were post-fixed in $2 \%$ buffered osmium tetroxide for two hours and dehydrated by a graded ethanol series. The obtained pieces were embedded in LR White resin (London Resin Company) and placed in an oven at $60^{\circ} \mathrm{C}$ for $48 \mathrm{~h}$ (Tomás et al. 2013).

Semi-fine $(0.8 \mu \mathrm{m})$ and ultra-fine $(90 \mathrm{~nm})$ cross-sections were cut using an ultramicrotome (Leica UC6, Vienna, Austria). Semi-fine sections were dyed with $1 \%$ toluidine blue to be viewed in a bright field with an Olympus $B X 60$ optic microscope. Pictures at $200 \times$ magnifications were taken with a digital camera ( $U-T V O .5 X C$, Olympus, Tokyo, Japan) to determine the fraction of mesophyll intercellular air spaces $\left(f_{\text {ias }}\right)$. Ultra-fine sections for transmission electron microscopy (TEM H600, Hitachi, Tokyo, Japan) were contrasted with uranyl acetate and lead citrate to obtain pictures at $1,500 \times$ and $30,000 \times$ magnifications. The chloroplasts surface area exposed to intercellular air spaces per leaf area $\left(\mathrm{S}_{\mathrm{c}} / \mathrm{S}\right)$ and the cell wall thickness $\left(\mathrm{T}_{\mathrm{cw}}\right)$ were measured from ultra-fine images at $1,500 \times$ and $30,000 \times$ magnifications, respectively. A cell curvature correction factor was determined according to Thain (1983) making an average length/width ratio of five randomly selected cells from both palisade and spongy mesophyll types for $\mathrm{S}_{\mathrm{c}} / \mathrm{S}$ estimation. Final values for measured parameters were obtained as an average of ten measurements from randomly selected cell structures using the ImageJ software (Wayne Rasband/NIH, Bethesda, MD, USA).

Cell wall extraction and fractionation: The same leaves used for gas exchange and anatomy sampling were kept under dark conditions overnight to minimize starch content. The following morning, around $1 \mathrm{~g}$ of fresh leaf tissue per plant was cut in small pieces and they were placed in glass tubes containing absolute ethanol (1:10, w/v). They were boiled until bleached and cleaned twice with acetone $>95 \%$ obtaining the alcohol insoluble residue (AIR), an approximation of the total isolated cell wall content. After dried, samples were grounded and starch remains were removed with $\alpha$-amylase digestion. Then, three analytical replicates of each AIR weighting $3 \mathrm{mg}$ were taken to be hydrolyzed with $2 \mathrm{M}$ trifluoroacetic acid for an hour at $121^{\circ} \mathrm{C}$. They were centrifuged at $13,000 \times g$ for the obtention of two phases: the supernatant (noncellulosic cell wall components) and the pellet (cellulosic cell wall components). Whilst the supernatant was kept at $-20^{\circ} \mathrm{C}$ to quantify hemicelluloses and uronic acids (i.e., pectins), the pellet was cleaned twice with distilled water and acetone $>95 \%$. Once dried, pellets were hydrolyzed in $200 \mu \mathrm{l}$ sulphuric acid $72 \%$ (w/v) for an hour, diluted to $6 \mathrm{ml}$ with distilled water, and heated until degradation. Once cooled, the obtained aqueous samples were used for cellulose quantification. Cellulose and hemicellulose quantifications were determined following Dubois et al. (1956). Thus, samples absorbance was read at $490 \mathrm{~nm}$ and both sugars concentrations were estimated by interpolating sample values from a glucose calibration curve. Finally, pectin quantification was performed following Blumenkrantz and Asboe-Hansen (1973). Hence, samples absorbance was read at $520 \mathrm{~nm}$ and pectin content was calculated by interpolating sample values from a galacturonic acid calibration curve. In all cases, a Multiskan Sky Microplate spectrophotometer (ThermoFisher Scientific) was used.

Pressure-volume curves: A fully developed leaf neighboring the one used for the gas exchange was rehydrated with distilled water and kept under dark conditions overnight. The next morning, leaf water potential and mass were measured simultaneously to obtain pressurevolume $(P-V)$ curves of, at least, ten points. Leaf water potential was determined using a pressure chamber (Model 600D, PMS Instrument Company, Albany, USA). From $P-V$ curves analysis, leaf water potential at turgor loss point $\left(\Psi_{\text {tlp }}\right)$, osmotic potential at full turgor $\left(\pi_{\mathrm{o}}\right)$, relative water content at turgor loss point $\left(\mathrm{RWC}_{\mathrm{tlp}}\right)$, apoplastic water fraction $\left(a_{\mathrm{f}}\right)$, and leaf area specific capacitance at full turgor $\left(C^{*}{ }_{\mathrm{ft}}\right)$ were obtained (Sack and Pasquet-Kok $2011)$. The bulk modulus of elasticity $(\varepsilon)$ was determined using standardized major axes (SMA; Sack et al. 2003).

Leaf structure: The same leaves used for $P-V$ curves were utilized to calculate the leaf mass area (LMA), the leaf density (LD), and the leaf area (LA) (PérezHarguindeguy et al. 2013). Leaves were rehydrated overnight and pictures of the LA including the petiole were analyzed with the ImageJ software (Wayne Rasband/ $\mathrm{NIH})$. Then, leaves were placed in an oven at $70^{\circ} \mathrm{C}$ for $72 \mathrm{~h}$ to obtain their dry mass. Leaf thickness was determined from six measurements per leaf avoiding main veins with a digital caliper. Thickness per area was used as a proxy to calculate LD.

Statistical analysis: Thompson test was performed to detect and eliminate outliers for all studied parameters. Two-way analysis of variance (ANOVA) and subsequent LSD test was assessed to determine significant $(P<0.05)$ 'species' and 'treatments' effects and differences between groups, respectively. All analyses were performed using the $R$ statistical software (ver. 3.2.2, $R$ Core Team, Vienna, Austria). 


\section{Results}

Physiological characterization: Under control conditions, $H$. annuus achieved the highest $P_{\mathrm{N}}$ and $g_{\mathrm{s}}[26.30 \pm 2.27$ $\mu \mathrm{mol}\left(\mathrm{CO}_{2}\right) \mathrm{m}^{-2} \mathrm{~s}^{-1}$ and $0.40 \pm 0.06 \operatorname{mol}\left(\mathrm{CO}_{2}\right) \mathrm{m}^{-2} \mathrm{~s}^{-1}$, respectively], which were largely reduced under water deficit stress (Fig. 1A,B). Contrarily, G. biloba showed much lower assimilation under control conditions [7.91 \pm $0.43 \mu \mathrm{mol}\left(\mathrm{CO}_{2}\right) \mathrm{m}^{-2} \mathrm{~s}^{-1}$, but neither $P_{\mathrm{N}}$ nor $g_{\mathrm{s}}$ experienced significant changes due to water deficit stress (Fig. 1A,B). Only $H$. annuus experienced an increase in $\mathrm{WUE}_{\mathrm{i}}$ under water deficit stress conditions (Fig. 1C). Additionally, water-stressed $H$. annuus also showed reductions of both $g_{\mathrm{m}}$ (Fig. 1D) and ETR, the latter being also slightly reduced in $G$. biloba (Fig. $1 E$ ). Finally, $R_{\text {light }}$ only revealed differences at $P=0.053$ for the 'treatments' effect as it slightly decreased under water deficit stress (Fig. $1 F$ ).

Leaf water relations: No treatment effect was detected for both $\Psi_{\text {tlp }}$ and $\pi_{\mathrm{o}}(P=0.337$ and 0.139 , respectively $)$ (Fig. $2 A, C$ ). Although $\mathrm{RWC}_{\text {tlp }}$ was maintained in G. biloba, it increased in water-stressed $H$. annuus in comparison to control (Fig. 2B). However, water-stressed G. biloba leaves were almost three-folds more rigid than control ones $(61.17 \pm 14.32$ and $21.15 \pm 2.36 \mathrm{MPa}$, respectively; Fig. 2D). Water deficit stress increased $a_{\mathrm{f}}$ and $C^{*}{ }_{\mathrm{ft}}$ in $H$. annuus $\left[0.55 \pm 0.03\right.$ and $1.96 \pm 0.25 \mathrm{~mol}\left(\mathrm{H}_{2} \mathrm{O}\right) \mathrm{m}^{-2}$ $\mathrm{MPa}^{-1}$, respectively], but no changes were detected in G. biloba (Fig. 2E,F).
Leaf structural and anatomical traits: Under water deficit stress conditions, H. annuus and G. biloba experienced an increase in both LMA and LD, being more marked in the latter species as they doubled control values (Table 1). An opposite pattern was found for LA, which decreased significantly under water deficit stress conditions, especially in G. biloba (Table 1). However, water deprivation did not significantly change anatomical parameters (i.e., $f_{\text {ias }}, \mathrm{S}_{\mathrm{c}} / \mathrm{S}$, and $\mathrm{T}_{\mathrm{cw}}$ ) in none of the two species (Table 1), which were evaluated from similar pictures to those from Fig. 3.

Leaf cell wall composition: Water deficit stress induced different changes in cell wall composition in the two species. G. biloba significantly increased hemicelluloses while slightly decreasing cellulose, with no changes in the total AIR and pectins (Table 2). Instead, $H$. annuus significantly enhanced the total AIR with also increased amounts of cellulose, hemicelluloses, and pectins in a similar proportion (Table 2).

\section{Discussion}

A classic response to water deficit stress involves a reduction of $P_{\mathrm{N}}$ associated to decreased leaf overall $\mathrm{CO}_{2}$ diffusion (i.e., $g_{\mathrm{s}}$ and $g_{\mathrm{m}}$ ) (Chaves et al. 2002, 2008; Flexas et al. 2004, 2012; Nadal and Flexas 2019), which promotes enhanced $\mathrm{WUE}_{\mathrm{i}}$ due to larger descents in $g_{\mathrm{s}}$ than in $g_{\mathrm{m}}$ (Flexas et al. 2013). In the current study, this pattern was only observed in water-stressed $H$. annuus plants as $P_{\mathrm{N}}, g_{\mathrm{s}}$, and $g_{\mathrm{m}}$ did not significantly decrease in G. biloba

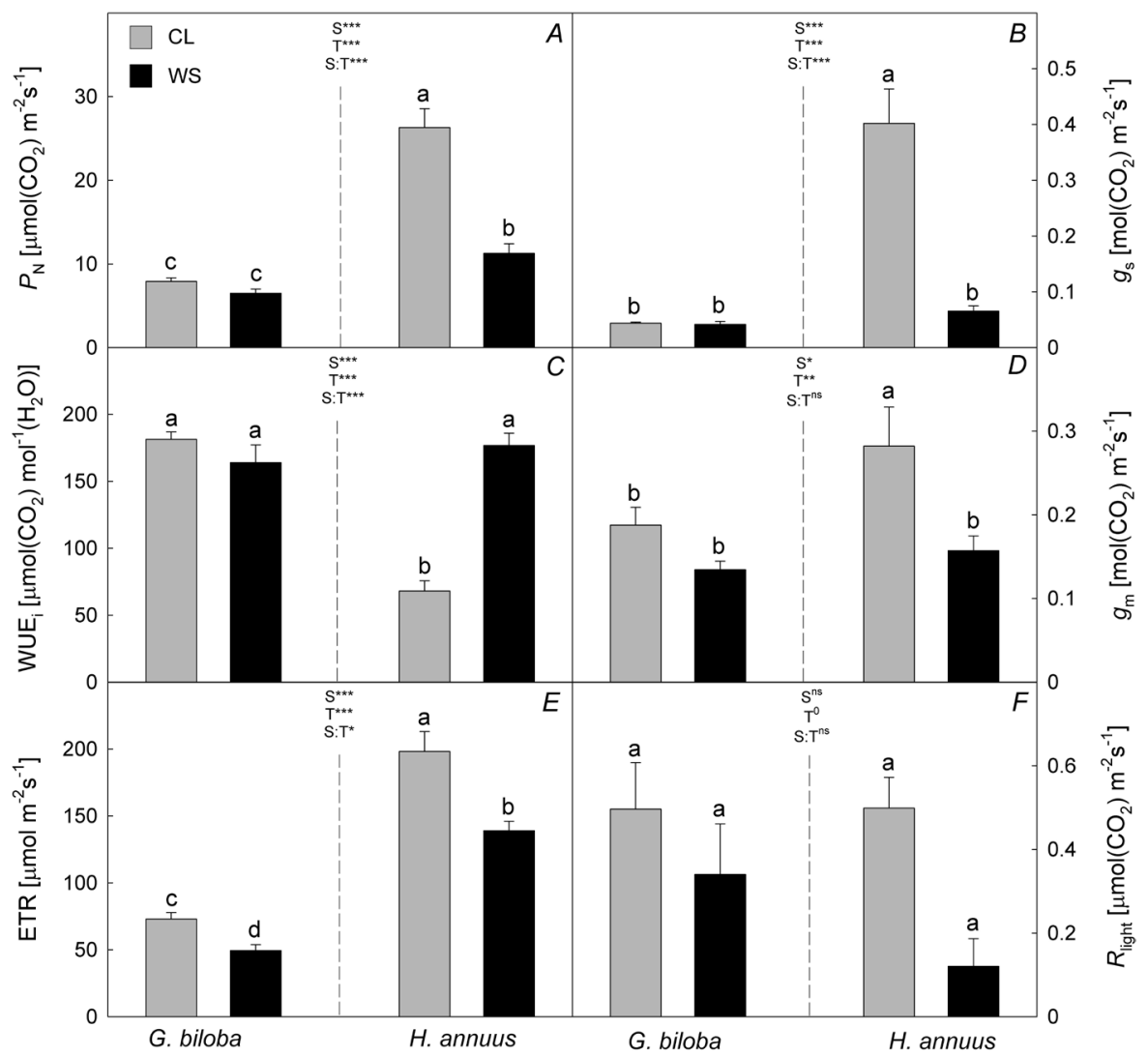

Fig. 1. (A) Net photosynthetic rate $\left(P_{\mathrm{N}}\right),(B)$ stomatal conductance $\left(g_{\mathrm{s}}\right)$, $(C)$ intrinsic water-use efficiency $\left(\mathrm{WUE}_{\mathrm{i}}\right),(D)$ mesophyll conductance $\left(g_{\mathrm{m}}\right),(E)$ electron transport rate (ETR), and $(F)$ light respiration $\left(R_{\text {light }}\right)$ in Ginkgo biloba and Helianthus annuus across conditions (CL - control, WS - water deficit stress). Species (S) and treatments (T) effects were quantified by two-way ANOVA and differences between groups were addressed by LSD test. Different superscript letters indicate significant differences. Significance: ${ }^{* * *} P<0.001 ;{ }^{* *}<0.01 ;{ }^{*}<0.05 ;{ }^{0}<0.1$ ns $>0.1$. Values are means $\pm \mathrm{SE}$ $(n=5-6)$. 


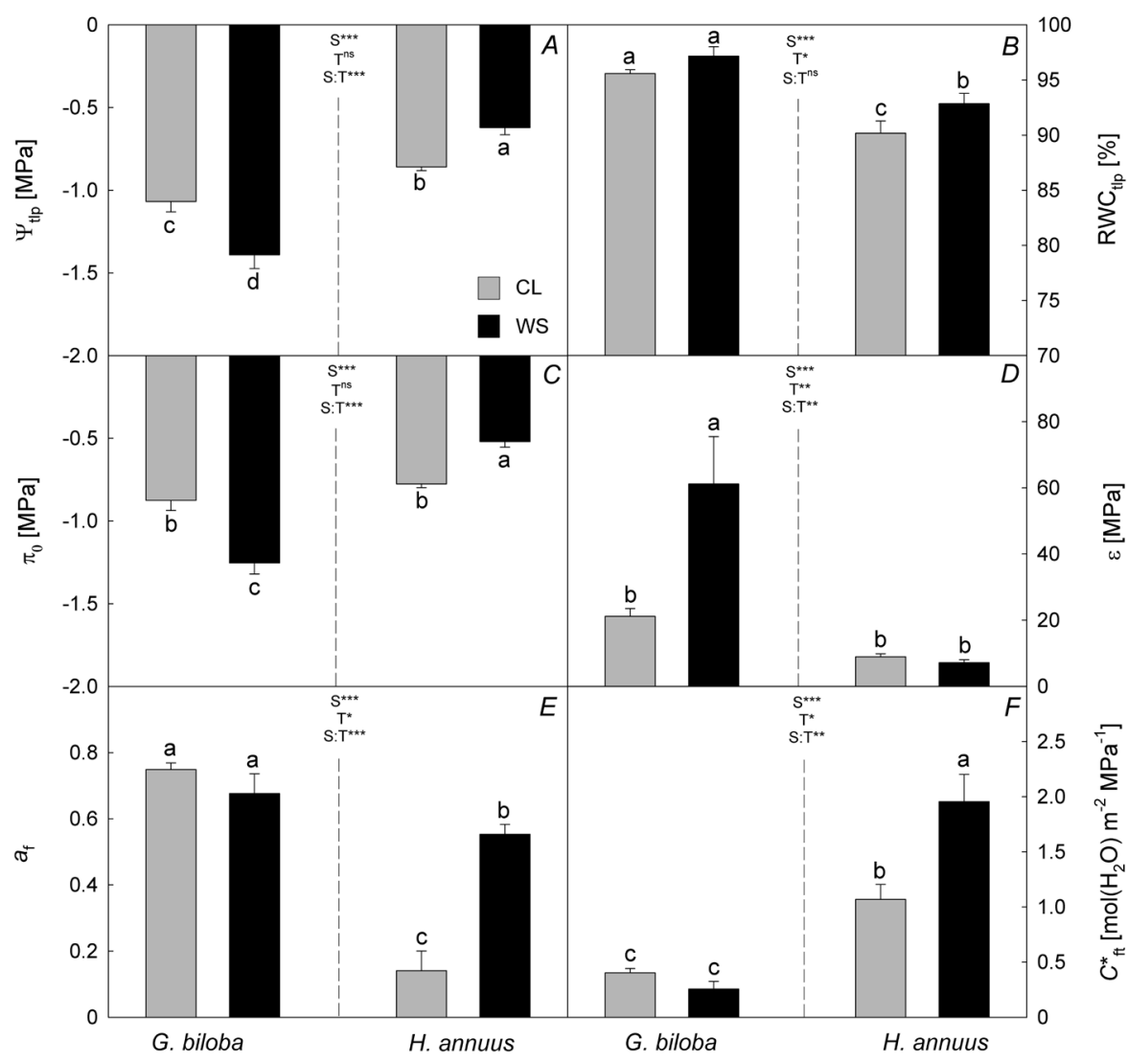

Fig. 2. (A) Water potential at turgor loss point $\left(\Psi_{\text {tpp }}\right),(B)$ relative water content at turgor loss point $\left(\mathrm{RWC}_{\mathrm{tp}}\right)$, (C) osmotic potential at full turgor $\left(\pi_{\mathrm{o}}\right),(D)$ bulk modulus of elasticity $(\varepsilon),(E)$ apoplastic water fraction $\left(a_{\mathrm{f}}\right)$, and $(F)$ leaf area specific capacitance at full turgor $\left(C^{*}{ }_{\mathrm{ft}}\right)$ in Ginkgo biloba and Helianthus annuus across conditions (CL control, WS - water deficit stress). Species (S) and treatments (T) effects were quantified by two-way ANOVA and differences between groups were addressed by LSD test. Significance: ${ }^{* * *} P<0.001 ;{ }^{* *}<0.01$; ${ }^{*}<0.05 ;{ }^{0}<0.1 ;{ }^{\text {ns }}>0.1$. Values are means \pm SE $(n=5-6)$.

Table 1. Leaf structural and anatomical traits of Ginkgo biloba and Helianthus annuus across conditions (CL - control, WS - water deficit stress). Average values $\pm \mathrm{SE}$ are shown for leaf mass area (LMA), leaf density (LD), leaf area (LA), fraction of mesophyll intercellular air spaces $\left(f_{\text {ias }}\right)$, chloroplasts surface area exposed to intercellular air spaces per leaf area $\left(\mathrm{S}_{\mathrm{c}} / \mathrm{S}\right)$ and cell wall thickness $\left(\mathrm{T}_{\mathrm{cw}}\right)$. Species and treatments effects were quantified by two-way ANOVA and differences between groups were addressed by LSD test. Different superscript letters indicate significant differences. $n=5-6$.

\begin{tabular}{lllllrl}
\hline Species and treatments & LMA $\left[\mathrm{g} \mathrm{m}^{-2}\right]$ & $\mathrm{LD}\left[\mathrm{g} \mathrm{cm}^{-3}\right]$ & $\mathrm{LA}\left[\mathrm{cm}^{2}\right]$ & $f_{\text {ias }}[\%]$ & $\mathrm{S}_{\mathrm{c}} / \mathrm{S}\left[\mathrm{m}^{2} \mathrm{~m}^{-2}\right]$ & $\mathrm{T}_{\mathrm{cw}}[\mu \mathrm{m}]$ \\
\hline G. biloba $-\mathrm{CL}$ & $41.42 \pm 1.22^{\mathrm{bc}}$ & $0.15 \pm 0.00^{\mathrm{c}}$ & $85.36 \pm 8.34^{\mathrm{a}}$ & $30.87 \pm 3.95^{\mathrm{b}}$ & $9.73 \pm 1.28^{\mathrm{b}}$ & $0.39 \pm 0.01^{\mathrm{a}}$ \\
G. biloba $-\mathrm{WS}$ & $89.52 \pm 5.16^{\mathrm{a}}$ & $0.31 \pm 0.02^{\mathrm{a}}$ & $21.50 \pm 9.61^{\mathrm{c}}$ & $25.13 \pm 1.83^{\mathrm{b}}$ & $10.92 \pm 1.13^{\mathrm{b}}$ & $0.42 \pm 0.03^{\mathrm{a}}$ \\
H. annuus $-\mathrm{CL}$ & $32.04 \pm 0.71^{\mathrm{c}}$ & $0.16 \pm 0.00^{\mathrm{c}}$ & $40.79 \pm 6.03^{\mathrm{b}}$ & $45.50 \pm 2.39^{\mathrm{a}}$ & $17.24 \pm 1.48^{\mathrm{a}}$ & $0.18 \pm 0.01^{\mathrm{b}}$ \\
H. annuus $-\mathrm{WS}$ & $48.18 \pm 1.02^{\mathrm{b}}$ & $0.22 \pm 0.00^{\mathrm{b}}$ & $21.37 \pm 0.49^{\mathrm{c}}$ & $40.31 \pm 0.58^{\mathrm{a}}$ & $18.74 \pm 1.59^{\mathrm{a}}$ & $0.16 \pm 0.01^{\mathrm{b}}$ \\
Species & $<0.001$ & 0.010 & 0.016 & $<0.001$ & $<0.001$ & $<0.001$ \\
Treatments & $<0.001$ & $<0.001$ & $<0.001$ & 0.058 & 0.347 & 0.708 \\
Species:Treatments & $<0.001$ & $<0.001$ & $<0.001$ & 0.921 & 0.914 & 0.177 \\
\hline
\end{tabular}

(Fig. 1A-D). Despite opposite patterns for photosynthesis regulation under water deficit stress, both species modified their foliage structure (i.e., increased LMA and LD, see Table 1) as previously reported by Niinemets et al. (2009). Additionally, water deficit stress strongly limited leaf development in both species as LA decreased significantly (Table 1), which has been described as a typical response to water deficit stress (Chaves et al. 2002). However, although Chartzoulakis et al. (2002) and Hafez et al. (2020) reported modifications in leaf, mesophyll, and epidermis thicknesses as well as in $f_{\text {ias }}$ testing avocado and barley, respectively, under water deprivation, Tomás et al. (2014) did not detect strong subcellular anatomical alterations in water-stressed grapevine cultivars. In fact, in the present study neither $\mathrm{T}_{\mathrm{cw}}$ nor other subcellular anatomical traits classically affecting $g_{\mathrm{m}}$ were modified under water deficit stress (Table 1), suggesting that decreased $g_{\mathrm{m}}$ in water-stressed $H$. annuus might be due to other nonstudied characteristics (e.g., aquaporins and/or carbonic anhydrases, see Pérez-Martín et al. 2014).

Poorter et al. (2009) proposed that LD could reflect, to some extent, the cell wall content per leaf. Nonetheless, AIR variations only followed the same pattern as LD in $H$. annuus, as the slight increase detected in G. biloba 
was not significant (Table 2). AIR enhancement due to water deficit stress was previously detected in N. sylvestris (Clemente-Moreno et al. 2019) and $V$. vinifera (RoigOliver et al. 2020). Concerning specific cell wall main composition, it has been reported that variations in cellulose content may depend, for instance, on species, specific plant tissues, plants' age, and/or level of water deficit (Sweet et al. 1990, Zheng et al. 2014, ClementeMoreno et al. 2019, Roig-Oliver et al. 2020). Thus,
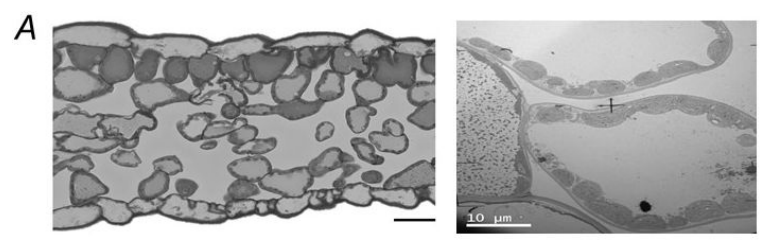

B
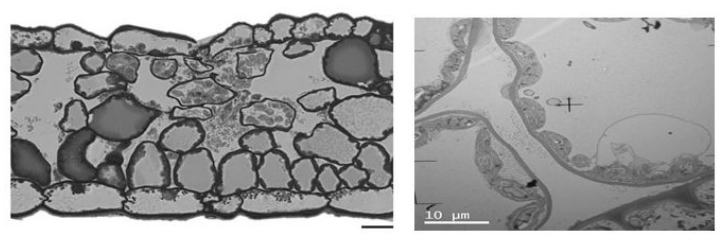

C
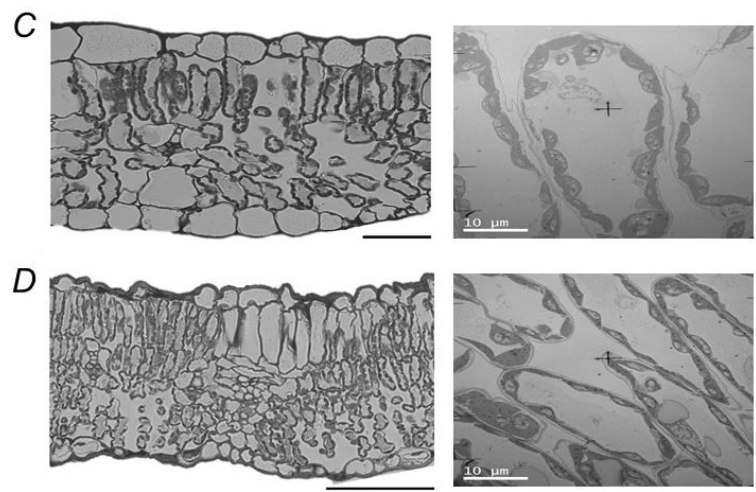

Fig. 3. Representative micrographs from semi-fine (left) and ultra-fine (right) cross-sections taken at $200 \times$ and at $1,500 \times$ magnifications, respectively, for Ginkgo biloba $(A, B)$ and Helianthus annuus $(C, D)$ under control and water deficit stress conditions, respectively. Black scale bars $=100 \mu \mathrm{m}$. Detailed quantitative analyses of studied anatomical parameters are reported in Table 1 . cellulose increased in $H$. annuus as previously shown for other species (Sweet et al. 1990, Clemente-Moreno et al. 2019, Roig-Oliver et al. 2020), but slightly decreased in G. biloba (Table 2). However, hemicelluloses have been found to either increase (Vicré et al. 1999), decrease (Sweet et al. 1990, Roig-Oliver et al. 2020), or stay constant (Clemente-Moreno et al. 2019) after exposure to water deficit stress. In our study, both species, especially G. biloba, presented increased amounts of hemicelluloses under water deficit stress (Table 2). Finally, pectins usually increase during water deficit because they play a key role in adjusting cell wall flexibility, thus, controlling cell wall hydric status (Sweet et al. 1990, Vicré et al. 1999, 2004; Cosgrove 2005, Leucci et al. 2008, Moore et al. 2008, 2013; Le Gall et al. 2015, Tenhaken 2015, Houston et al. 2016, Clemente-Moreno et al. 2019, Rui and Dinnery 2019, Roig-Oliver et al. 2020). However, in our study pectins were only enhanced in water-stressed $H$. annuus in a similar proportion to cellulose and hemicelluloses (Table 2). Additionally, the potential importance of pectins in determining $\varepsilon$ adjustments has already been proposed (Moore et al. 2008, Solecka et al. 2008, Niinemets 2016) and Roig-Oliver et al. (2020) provided empirical evidence for this in grapevines. Surprisingly, $H$. annuus maintained $\varepsilon$ under water deficit stress, while $G$. biloba - having kept pectins constant - drastically enhanced leaves rigidity once subjected to water deficit stress (Fig. 2D) as usually reported for other species (Bowman and Roberts 1985, Lo Gullo and Salleo 1988, Abrams 1990, Kloeppel et al. 1994). Although more experimental conditions should be tested to set concluding statements, our results suggest that $\varepsilon$ adjustments in water-stressed $G$. biloba could be much more related to changes in leaf structure (i.e., decreased LA and enhanced LMA and LD) and hemicelluloses rather than to other cell wall components. However, while increased $\varepsilon$ and LD have been proposed to involve reductions in $g_{\mathrm{m}}$ (Niinemets et al. 2009, Nadal et al. 2018), G. biloba was able to maintain $g_{\mathrm{m}}$ at control values under water deficit stress conditions. Oppositely, $H$. annuus differed from the previous strategy as leaf structure and cell wall composition changes were not reflected in $\varepsilon$ modifications. Instead, increased AIR, cellulose, hemicelluloses, and pectins under water deficit stress were reflected as an increase in $a_{\mathrm{f}}$ and $C^{*}{ }_{\mathrm{ft}}$ (Fig. $\left.2 E, F\right)$.

Table 2. Leaf cell wall composition of Ginkgo biloba and Helianthus annuus across conditions (CL - control, WS - water deficit stress). Average values \pm SE are shown for alcohol insoluble residue (AIR), cellulose, hemicelluloses, and pectins contents. Species and treatments effects were quantified by two-way ANOVA and differences between groups were addressed by LSD test. Different superscript letters indicate significant differences. $n=5-6$.

\begin{tabular}{lllll}
\hline Species and treatments & AIR $\left[\mathrm{g} \mathrm{g}^{-1}(\mathrm{DM})\right]$ & Cellulose $\left[\mathrm{mg} \mathrm{g}^{-1}(\mathrm{AIR})\right]$ & Hemicelluloses $\left[\mathrm{mg} \mathrm{g}^{-1}(\mathrm{AIR})\right]$ & Pectins [mg g $\left.{ }^{-1}(\mathrm{AIR})\right]$ \\
\hline G. biloba $-\mathrm{CL}$ & $0.16 \pm 0.03^{\mathrm{a}}$ & $125.2 \pm 12.9^{\mathrm{a}}$ & $176.5 \pm 18.3^{\mathrm{b}}$ & $71.27 \pm 6.52^{\mathrm{b}}$ \\
G. biloba $-\mathrm{WS}$ & $0.19 \pm 0.01^{\mathrm{a}}$ & $100.2 \pm 11.6^{\mathrm{ab}}$ & $261.4 \pm 30.6^{\mathrm{a}}$ & $79.60 \pm 4.16^{\mathrm{b}}$ \\
H. annuus $-\mathrm{CL}$ & $0.09 \pm 0.01^{\mathrm{b}}$ & $86.6 \pm 8.8^{\mathrm{b}}$ & $79.7 \pm 12.5^{\mathrm{c}}$ & $73.09 \pm 12.09^{\mathrm{b}}$ \\
H. annuus $-\mathrm{WS}$ & $0.15 \pm 0.01^{\mathrm{a}}$ & $128.7 \pm 5.2^{\mathrm{a}}$ & $156.2 \pm 9.8^{\mathrm{b}}$ & $103.68 \pm 3.45^{\mathrm{a}}$ \\
Species & $<0.001$ & 0.622 & $<0.001$ & 0.051 \\
Treatments & 0.012 & 0.406 & 0.001 & 0.013 \\
Species:Treatments & 0.351 & 0.003 & 0.847 & 0.133 \\
\hline
\end{tabular}


To our knowledge, this study provides the first evidence on how changes in cell wall main composition may play a role in determining different strategies to face water deficit stress by adjustments in $\varepsilon$ and/or $g_{\mathrm{m}}$ testing species from different phylogenetic groups. Contrary to ClementeMoreno et al. (2019) and Roig-Oliver et al. (2020), in the two species studied here, water deficit stress induced changes in cell wall composition that did not affect $g_{\mathrm{m}}$ and photosynthesis, but differently modified water relations parameters. Thus, more detailed studies using a larger range of species and treatments are required for a better understanding of how cell wall composition - including other cell wall compounds such as lignins and cell wallbound phenolics - can involve changes in leaf physiology and to what extent these responses are species-dependent and/or change across plants phylogeny.

\section{References}

Abrams M.D.: Adaptations and responses to drought in Quercus species of North America. - Tree Physiol. 7: 227-238, 1990.

Álvarez-Arenas T.E.G., Sancho-Knapik D., Peguero-Pina J.J. et al.: Non-contact ultrasonic resonant spectroscopy resolves the elastic properties of layered plant tissues. - Appl. Phys. Lett. 113: 253704, 2018.

Baldwin L., Domon J.M., Klimek J.F. et al.: Structural alteration of cell wall pectins accompanies pea development in response to cold. - Phytochemistry 104: 37-47, 2014.

Bartels D., Classen B.: Structural investigations on arabinogalactan-proteins from a lycophyte and different monilophytes (ferns) in the evolutionary context. - Carbohydr. Polym. 172: 342-351, 2017.

Bellasio C., Beerling D.J., Griffiths H.: An Excel tool for deriving key photosynthetic parameters from combined gas exchange and chlorophyll fluorescence: theory and practice. - Plant Cell Environ. 39: 1180-1197, 2016.

Bernacchi C.J., Portis A.R., Nakano H. et al.: Temperature response of mesophyll conductance. Implications for the determination of Rubisco enzyme kinetics and for limitations to photosynthesis in vivo. - Plant Physiol. 130: 1992-1998, 2002.

Blumenkrantz N., Asboe-Hansen G.: New method for quantitative determination of uronic acids. - Anal. Biochem. 54: 484-489, 1973.

Bowman W.D., Roberts S.W.: Seasonal changes in tissue elasticity in chaparral shrubs. - Physiol. Plantarum 65: 233236, 1985.

Carpita N.C., Gibeaut D.M.: Structural models of primary cell walls in flowering plants: consistency of molecular structure with the physical properties of the walls during growth. Plant J. 3: 1-30, 1993.

Carriquí M., Cabrera H.M., Conesa M.À. et al.: Diffusional limitations explain the lower photosynthetic capacity of ferns as compared with angiosperms in a common garden study. Plant Cell Environ. 38: 448-460, 2015.

Carriquí M., Nadal M., Clemente-Moreno M.J. et al.: Cell wall composition strongly influences mesophyll conductance in gymnosperms. - Plant J. 103: 1372-1385, 2020.

Carriquí M., Roig-Oliver M., Brodribb T.J. et al.: Anatomical constraints to nonstomatal diffusion conductance and photosynthesis in lycophytes and bryophytes. - New Phytol. 222: 1256-1270, 2019.

Carvalho C.P., Hayashi A.H., Braga M.R., Nievola C.C.: Biochemical and anatomical responses related to the in vitro survival of the tropical bromeliad Nidularium minutum to low temperatures. - Plant Physiol. Bioch. 71: 144-154, 2013.

Chartzoulakis K., Patakas A., Kofidis G. et al.: Water stress affects leaf anatomy, gas exchange, water relations and growth of two avocado cultivars. - Sci. Hortic.-Amsterdam 95: 39-50, 2002.

Chaves M.M., Flexas J., Pinheiro C.: Photosynthesis under drought and salt stress: regulation mechanisms from whole plant to cell. - Ann. Bot.-London 103: 551-560, 2008.

Chaves M.M., Pereira J.S., Maroco J. et al.: How plants cope with water stress in the field. Photosynthesis and Growth. Ann. Bot.-London 89: 907-916, 2002.

Clemente-Moreno M.J., Gago J., Díaz-Vivancos P. et al.: The apoplastic antioxidant system and altered cell wall dynamics influence mesophyll conductance and the rate of photosynthesis. - Plant J. 99: 1031-1046, 2019.

Cosgrove D.J.: Relaxation in a high-stress environment: the molecular bases of extensible cell walls and cell enlargement. Plant Cell 9: 1031-1041, 1997.

Cosgrove D.J.: Growth of the plant cell wall. - Nat. Rev. Mol. Cell Biol. 6: 850-861, 2005.

Dubois M., Gilles K.A., Hamilton J.K. et al:: Colorimetric method for determination of sugars and related substances. Anal. Chem. 28: 350-356, 1956.

Ellsworth P.V., Ellsworth P.Z., Koteyeva N.K., Cousins A.B.: Cell wall properties in Oryza sativa influence mesophyll $\mathrm{CO}_{2}$ conductance. - New Phytol. 219: 66-76, 2018.

Evans J.R., Kaldenhoff R., Genty B., Terashima I.: Resistance along the $\mathrm{CO}_{2}$ diffusion pathway inside leaves. - J. Exp. Bot. 60: 2235-2248, 2009.

Flexas J., Barbour M.M., Brendel O. et al.: Mesophyll conductance to $\mathrm{CO}_{2}$ : an unappreciated central player in photosynthesis. - Plant Sci. 193-194: 70-84, 2012.

Flexas J., Bota J., Loreto F. et al.: Diffusive and metabolic limitations to photosynthesis under drought and salinity in $\mathrm{C}_{3}$ plants. - Plant Biol. 6: 269-279, 2004.

Flexas J., Díaz-Espejo A., Berry J.A. et al.: Analysis of leakage in IRGA's leaf chambers of open gas exchange systems: quantification and its effects in photosynthesis parameterization. - J. Exp. Bot. 58: 1533-1543, 2007.

Flexas J., Niinemets Ü., Gallé A. et al.: Diffusional conductances to $\mathrm{CO}_{2}$ as a target for increasing photosynthesis and photosynthetic water-use efficiency. - Photosynth. Res. 117: 45-59, 2013.

Galmés J., Medrano H., Flexas J.: Acclimation of Rubisco specificity factor to drought in tobacco: discrepancies between in vitro and in vivo estimations. - J. Exp. Bot. 57: 3659-3667, 2006.

Hafez Y., Attia K., Alamery S. et al.: Beneficial effects of biochar and chitosan on antioxidative capacity, osmolytes accumulation, and anatomical characters of water-stressed barley plants. - Agronomy 10: 630, 2020.

Houston K., Tucker M.R., Chowdhury J. et al.: The plant cell wall: a complex and dynamic structure as revealed by the responses of genes under stress conditions. - Front. Plant Sci. 7: 984, 2016.

Kloeppel B.D., Kubiske M.E., Abrams M.D.: Seasonal tissue water relations of four successional Pennsylvania barrens species in open and understory environments. - Int. J. Plant Sci. 155: 73-79, 1994.

Le Gall H., Philippe F., Domon J.M. et al.: Cell wall metabolism in response to abiotic stress. - Plants-Basel 4: 112-166, 2015.

Leucci M.R., Lenucci M.S., Piro G., Dalessandro G.: Water stress and cell wall polysaccharides in the apical root zone of wheat cultivars varying in drought tolerance. - J. Plant Physiol. 165: 1168-1180, 2008.

Lo Gullo M.A., Salleo S.: Different strategies of drought 
resistance in three Mediterranean sclerophyllous trees growing in the same environmental conditions. - New Phytol. 108: 267-276, 1988.

Moore J.P., Farrant J.M., Driouich A.: A role for pectin-associated arabinans in maintaining the flexibility of the plant cell wall during water deficit stress. - Plant Signal. Behav. 3: 102-104, 2008.

Moore J.P., Nguema-Ona E.E., Vicré-Gibouin M. et al.: Arabinose-rich polymers as an evolutionary strategy to plasticize resurrection plant cell walls against desiccation. Planta 237: 739-754, 2013.

Nadal M., Flexas J.: Variation in photosynthetic characteristics with growth form in a water-limited scenario: Implications for assimilation rated and water use efficiency in crops. - Agr. Water Manage. 216: 457-472, 2019.

Nadal M., Flexas J., Gulías J.: Possible link between photosynthesis and leaf modulus of elasticity among vascular plants: A new player in leaf traits relationships? - Ecol. Lett. 21: 1372-1379, 2018.

Niinemets Ü.: Global-scale climatic controls of leaf dry mass per area, density, and thickness in trees and shrubs. - Ecology 82: 453-469, 2001.

Niinemets Ü.: Does the touch of cold make evergreen leaves tougher? - Tree Physiol. 36: 267-272, 2016.

Niinemets Ü., Díaz-Espejo A., Flexas J. et al.: Role of mesophyll diffusion conductance in constraining potential photosynthetic productivity in the field. - J. Exp. Bot. 60: 2249-2270, 2009.

Onoda Y., Wright I.J., Evans J.R. et al.: Physiological and structural tradeoffs underlying the leaf economics spectrum. New Phytol. 214: 1447-1463, 2017.

Peguero-Pina J.J., Sancho-Knapik D., Gil-Pelegrín E.: Ancient cell structural traits and photosynthesis in today's environment. - J. Exp. Bot. 68: 1389-1392, 2017.

Pérez-Harguindeguy N., Díaz S., Garnier E. et al.: New handbook for standardised measurement of plant functional traits worldwide. - Aust. J. Bot. 61: 167-234, 2013.

Pérez-Martín A., Michelazzo C., Torres-Ruiz J.M. et al.: Regulation of photosynthesis and stomatal and mesophyll conductance under water stress and recovery in olive trees: correlation with gene expression of carbonic anhydrase and aquaporins. - J. Exp. Bot. 65: 3143-3156, 2014.

Poorter H., Niinemets Ü., Poorter L. et al.: Causes and consequences of variation in leaf mass per area (LMA): a meta-analysis. - New Phytol. 182: 565-588, 2009.

Popper Z.A., Fry S.C.: Primary cell wall composition of pteridophytes and spermatophytes. - New Phytol. 164: 165174, 2004.

Popper Z.A., Michel G., Hervé C. et al: Evolution and diversity of plant cell walls: from algae to flowering plants. - Annu. Rev. Plant Biol. 62: 567-590, 2011.

Roig-Oliver M., Nadal M., Clemente-Moreno M.J. et al.: Cell wall components regulate photosynthesis and leaf water relations of Vitis vinifera cv. Grenache acclimated to contrasting environmental conditions. - J. Plant Physiol. 244: 153084, 2020.

Rui Y., Dinnery J.R.: A wall with integrity: surveillance and maintenance of the plant cell wall under stress. - New Phytol. 225: 1428-1439, 2019.

Sack L., Cowan P.D., Jaikumar N., Holbrook N.M.: The 'hydrology' of leaves: coordination of structure and function in temperate woody species. - Plant Cell Environ. 26: 13431356, 2003.

Sack L., Pasquet-Kok J.: Leaf pressure-volume curve parameters. PrometheusWiki contributors, 2011. Available at: http:// prometheuswiki.org/tiki-pagehistory.php? page $=$ Leaf $\% 20$ pressure-volume $\% 20$ curve\%20parameters\&preview $=16$.
Sarkar P., Bosneaga E., Auer M.: Plant cell walls throughout evolution: towards a molecular understanding of their design principles. - J. Exp. Bot. 60: 3615-3635, 2009.

Schiraldi A., Fessas D., Signorelli M.: Water activity in biological systems - A review. - Pol. J. Food Nutr. Sci. 62: 5-13, 2012.

Sharkey T.D.: What gas exchange data can tell us about photosynthesis. - Plant Cell Environ. 39: 1161-1163, 2016.

Solecka D., Zebrowski J., Kacperska A.: Are pectins involved in cold acclimation and de-acclimation of winter oil-seed rape plants? - Ann. Bot.-London 101: 521-530, 2008.

Somerville C., Bauer S., Brinistool G. et al.: Toward a systems approach to understanding plant cell walls. - Science 306: 2206-2211, 2004.

Sørensen I., Domozych D., Williats W.G.T.: How have plant cell walls evolved? - Plant Physiol. 153: 366-372, 2010.

Suwa R., Hakata H., Hara H. et al.: High temperature effects on photosynthate partitioning and sugar metabolism during ear expansion in maize (Zea mays L.) genotypes. - Plant Physiol. Bioch. 48: 124-130, 2010.

Sweet W.J., Morrison J.C., Labavitch J.M., Matthews M.A.: Altered synthesis and composition of cell wall of grape (Vitis vinifera L.) leaves during expansion and growth inhibiting water deficit. - Plant Cell Physiol. 31: 407-414, 1990.

Tenhaken R.: Cell wall remodelling under abiotic stress. - Front. Plant Sci. 5: 771, 2015.

Terashima I., Miyazawa S.I., Hanba Y.T.: Why are sun leaves thicker than shade leaves? Consideration based on analyses of $\mathrm{CO}_{2}$ diffusion in the leaf. - J. Plant Res. 114: 93-105, 2001.

Thain J.F.: Curvature correlation factors in the measurements of cell surface areas in plant tissues. - J. Exp. Bot. 34: 87-94, 1983.

Tomás M., Flexas J., Copolovici L. et al.: Importance of leaf anatomy in determining mesophyll diffusion conductance to $\mathrm{CO}_{2}$ across species: quantitative limitations and scaling up by models. - J. Exp. Bot. 64: 2269-2281, 2013.

Tomás M., Medrano H., Brugnoli E. et al:: Variability of mesophyll conductance in grapevine cultivars under water stress conditions in relation to leaf anatomy and water use efficiency. - Aust. J. Grape Wine Res. 20: 272-280, 2014.

Tosens T., Nishida K., Gago J. et al.: The photosynthetic capacity in 35 ferns and fern allies: mesophyll $\mathrm{CO}_{2}$ diffusion as a key trait. - New Phytol. 209: 1576-1590, 2016.

Tyree M.T., Jarvis P.G.: Water in tissues and cells. - In: Lange O.L., Nobel P.S., Osmond C.B., Ziegler H. (ed.): Physiological Plant Ecology II. Encyclopedia of Plant Physiology (New Series). Pp. 35-77. Springer Verlag, Berlin-Heidelberg 1982.

Veromann-Jürgenson L.L., Tosens T., Laanisto L., Niinemets Ü.: Extremely thick cell walls and low mesophyll conductance: welcome to the world of ancient living! - J. Exp. Bot. 68: 1639-1653, 2017.

Vicré M., Lerouxel O., Farrant J. et al:: Composition and desiccation-induced alterations of the cell wall in the resurrection plant Craterostigma wilmsii. - Physiol. Plantarum 120: 229-239, 2004.

Vicré M., Sherwin H.W., Driouich A. et al:: Cell wall characteristics and structure of hydrated and dry leaves of the resurrection plant Craterostigma wilmsii, a microscopical study. - J. Plant Physiol. 155: 719-726, 1999.

von Caemmerer S., Farquhar G., Berry J. et al.: Biochemical model of $\mathrm{C}_{3}$ photosynthesis. - In: Laisk A., Nedbal L., Govindjee (ed.): Photosynthesis in Silico: Understanding Complexity from Molecules to Ecosystems. Pp. 209-230. Springer, Dordrecht 2009.

Yin X., Struik P.C., Romero P. et al.: Using combined measurements of gas exchange and chlorophyll fluorescence to estimate parameters of a biochemical $\mathrm{C}_{3}$ photosynthesis 
model: a critical appraisal and a new integrated approach applied to leaves in a wheat (Triticum aestivum) canopy. Plant Cell Environ. 32: 448-464, 2009.

Yin X., Sun Z., Struik P.C., Gu J.: Evaluating a new method to estimate the rate of leaf respiration in the light by analysis of combined gas exchange and chlorophyll fluorescence measurements. - J. Exp. Bot. 62: 3489-3499, 2011.

Zheng M., Meng Y., Yang C. et al.: Protein expression changes during cotton fibre elongation in response to drought stress and recovery. - Proteomics 14: 1776-1795, 2014.

(C) The authors. This is an open access article distributed under the terms of the Creative Commons BY-NC-ND Licence. 